\title{
Inhibition of Staphylococcus aureus enterotoxin genes by using plant extracts
}

Inhibición de genes de enterotoxinas de Staphylococcus aureus usando extracto de plantas

Author:

Srwa A. Mohammed ${ }^{1}$

Mohammed I. J. Al-ani ${ }^{2}$

Dereh L. Mohammed ${ }^{3}$

Lina R. Salar ${ }^{4}$

Banaz M. Rasul ${ }^{5}$

\section{SCIENTIFIC RESEARCH}

How to cite this paper:

Mohammed S A., Al-ani M I J., Mohammed D L., Salar L R., and Rasul B M., Inhibition of Staphylococcus aureus enterotoxin genes by using plant extracts. Kurdistan region-Iraq. Innovaciencia. 2018; 6 (2): 1-8

http://dx.doi.org/10.15649/2346075X.469

Reception date:

Received: 05 May 2018

Accepted: 18 June 2018

Published: 28 December 2019

Keywords:

Staphylococcus aureus; Enterotoxin gene; Plasmid; Transformation.

\section{ABSTRACT}

Introduction: Enterotoxigenic Staphylococcus aureus is an important pathogen that causes septicemia and bacteremia and is often associated with serious complications, such as endocarditis and osteomyelitis. Some Staphylococcus enterotoxins require only minute quantities to be toxic in humans. The present study focused on investigation how to remove this problematic issue. Objectives: This study was conducted to inhibit $S$. aureus enterotoxin genes that obtained from positive blood culture bottles of patients at the pediatric hospital in Sulaimania city. Methods: Twenty five isolates of S. aureus were isolated among 100 positive blood culture bottles and determined the strains that produce enterotoxins through culture method. Then, the enterotoxin genes that located on plasmids were cured by two medicinal plants (Eugenia caryophyllata and Cinnamomum zeylanicum). Results: The results showed that nine out of 25 isolates were released enterotoxins from which the plasmid encoding enterotoxin genes were confirmed in four of them. And, two of the isolates were transferred to recipient DH10B E. coli isolate successfully. Methanol extracts of (E. caryophyllata and C. zeylanicum) were used at sub minimum inhibition concentration as curing agents. Conclusion: Methanol extracts of (E. caryophyllata and $C$. zeylanicum) have grate effect on eliminating the plasmids encoding enterotoxin gene of $S$. aureus.

\footnotetext{
1 Assistant Prof. at Koya University/ Faculty of Science and Health/ Medical Microbiology Department, Koya, Kurdistan region-Iraq, email: srwa.ali@koyauniversity.org. (Corresponding author).

2 Assistant Lecturer at Koya University/Faculty of Science and Health/ Medical Microbiology Department, Koya, Kurdistan region-Iraq, email: mohammed.isam@koyauniversity.org.

3 Plastic and reconstructive surgery Faruk Medical city Private Hospital Sulaimania, Iraq, email: dere44@icloud.com.

4 Assistant Reasearcher at Koya University/ Faculty of Science and Health/ Medical Microbiology Department, Koya, Kurdistan region-Iraq, email: lina00142087@gmail.com.

5 Assistant Reasearcher at Koya University/ Faculty of Science and Health/ Medical Microbiology Department, Koya, Kurdistan region-Iraq, email: banaz.200778@gmail.com.
} 


\section{INTRODUCCTION}

Staphylococcus aureus is an important pathogen. The bacterium is known as one of the most frequent pathogens in both community and nosocomial infections, and it causes septicemia, endocarditis, osteomyelitis, abscesses, pneumonia, wound infections, impetigo, cutaneous rash, in addition to various toxin-mediated disease ${ }^{(1)}$. In addition the combinations of toxin-mediated virulence, invasiveness, and antibiotic resistance are also play a major role in these manifestations ${ }^{(2)}$. Blood stream infection is often associated with serious complications. The complication rates rise with duration of untreated bacteremia (3). S. aureus is one of the leading causes of bacteremia, with high levels of accompanying morbidity and mortality (4). Furthermore, microbial illnesses are regulated by an array of virulence factors that contribute to the pathophysiology and survival of the pathogen in the host ${ }^{(5)}$. These factors include cell surface proteins, receptors, and adhesins that facilitate host colonization; capsular polysaccharides that confer protection from host immune system, and microbial toxins that cause host tissue damage $(6,7)$. Since microbial toxins play a prime role in the virulence and pathogenesis of microbes in the host, they are major targets for developing plant-derived compounds such as therapeutic interventions ${ }^{(8)}$. Reducing the expression of these virulence factors could control infections in humans ${ }^{(8)}$. Current study, focused on the effects of Eugenia caryophyllata and Cinnamomum zeylanicum crude extracts as antimicrobials agents against enterotoxin gene of $S$. aureus.

\section{MATERIALS AND METHOD}

Isolation and Identification: (100) samples of blood culture bottles were obtained directly from laboratory of Sulaimania Pediatric Hospital which have obtained from high fever patients with suspect- ed sepsis or bacteremia. Specimens were collected using the BacT/Alert bottles which must be accessioned and processed as quickly as possible. The computer detects a positive results by an increased rate of colour change to turbid ${ }^{(9)}$. Then, $(0.01 \mathrm{ml})$ of the suspected blood samples were streaked onto blood agar and incubated at $37^{\circ} \mathrm{C}$ for overnight. The presumptive colonies of $S$. aureus were further cultured onto mannitol salt agar (MSA) and repeatedly sub-cultured to get pure culture. The isolates were identified as $S$. aureus on the basis of Gram staining, colony morphology ${ }^{(10)}$, and biochemical tests (catalase test, coagulase test, DNase test and gelatinase test) $\stackrel{(11)}{\text {. }}$

Production of Enterotoxins: Purified bacterial colony were stabbed into brain heart infusion slant, after incubation for 24 hours at $37 \square \mathrm{C}$, one loopful of the growth from the slant was transferred to $5 \mathrm{ml}$ tubes of sterile saline solution to obtain a McFarland turbidity value of $300 \mathrm{CFU}\left(\mathrm{x} \mathrm{10}{ }^{6}\right.$. Four drops of this bacterial suspension were spread over the surface of brain heart infusion agar plate supplemented with phenol red $(0.02 \mathrm{gm} / 100 \mathrm{ml})$ ( $\mathrm{pH} 5.4)$, and then the medium was incubated at $37 \square \mathrm{C}$ for 24 hours. A positive result (enterotoxin production) was indicated by the medium color from yellow to red due to the change of phenol red color as respond to $\mathrm{pH}$ changes ( from 5.4 to 8.2$)^{(12)}$.

Isolation of plasmid DNA: Plasmid extractions were performed essentially by alkaline lysis method. A single colony of bacterial isolates was grown in 10 $\mathrm{ml}$ of LB broth containing $50 \mu \mathrm{g} / \mathrm{ml}$ penicillin $\mathrm{G}$ and incubated at $37 \mathrm{C}^{\circ}$ for $24 \mathrm{hr}$. with shaking. Bacterial cells were harvested by centrifugation at $10000 \mathrm{rpm}$ for $10 \mathrm{~min}$, and then transferred to sterile eppendorf tube when plasmid samples were turbid, proteinase $\mathrm{K}$ was added to the samples to a final concentration of $50 \mu \mathrm{g} / \mathrm{ml}$ and the mixtures were incubated 
for $30 \mathrm{~min}$ at $37^{\circ} \mathrm{C}$. After incubation with proteinase $\mathrm{K}$, plasmid DNA was extracted with phenol-chloroform and then precipitated with ethanol $\stackrel{(13)}{\text {. }}$.

\section{Transformation processes include:}

1-Competent cells preparation: Many bacteria can be made competent by exposure to a divalent or multivalent cation, such as calcium chloride, manganese chloride ${ }^{(14)}$.

2- DNA uptake: $100 \mu$ l of prepared plasmid DNA (0.1) $\mathrm{ml}$ added to tube containing $0.2 \mathrm{ml}$ of competent cells. The mixture was placed on ice for 30 minutes, exposed to heat shock at $42{ }^{\circ} \mathrm{C}$ for $6 \mathrm{~min}$ utes ${ }^{(15)}$. After that $1 \mathrm{ml}$ of fresh nutrient broth was added to transformation mixture, and incubated at $37 \mathrm{C}^{\circ}$ for 60 minutes to allow the expression of the enterotoxin genes. All samples of $0.1 \mathrm{ml}$ from transformation mixture were spread on the plates of brain heart infusion agar supplemented with phenol red ( $\mathrm{pH} 5.4)$ by adding $(0.02 \mathrm{gm} / 100 \mathrm{ml}) \stackrel{(16)}{\text {, and } 0.1}$ $\mathrm{ml}$ of competent cells spread on brain heart infusion agar containing phenol red as control. All plates were incubated at $37{ }^{\circ} \mathrm{C}$ for 24 hours for the selection of transformants in DH10B E. coli as described by $\stackrel{(17)}{\text {. }}$

Electrophoresis of plasmid DNA: Plasmid DNA was subjected to electrophoresis at $100 \mathrm{~mA}$ for 1.5 $\mathrm{h}$, using horizontal $0.8 \%$ agarose gels in TAE buffer ( $\mathrm{pH}$ 8.0) containing $50 \mathrm{mM}$ Tris, $20 \mathrm{mM}$ sodium acetate, $2 \mathrm{mM}$ EDTA, and $18 \mathrm{mM} \mathrm{NaCl} \stackrel{(18)}{\text {. Gels were }}$ stained with ethidium bromide $(2 \mu \mathrm{l})$.

Selection of medical plants for study: Clove (Eugenia caryophyllata and Cinnamomum zeylanicum) were obtained from local market in Sulaimani city then Preparation of methanol crude extracts were performed $\stackrel{(19)}{\text {. }}$.

\section{Determination of minimum inhibitory concen-} tration (MIC): The minimum inhibitory concentration was determined for plant extract, which inhibited bacterial growth. The test was compared to the control sample which consisted of $5 \mathrm{ml}$ of nutrient broth and $0.1 \mathrm{ml}$ of overnight culture of bacterial suspension, and then incubated at $37^{\circ} \mathrm{C}$ for 24 hours. The MIC of medicinal plant extracts were determined by turbidity method (spectrophotometric method) at $600 \mathrm{~nm}$ and the following dilution were prepared for each extract $(100,500,600,700,800$, 900, 1000, 2000, 3000, 4000, 5000, 6000 and 7000)

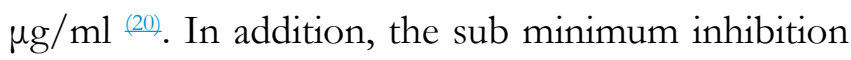
concentration (SMIC) of medicinal plant extracts was determined and used as curing agents.

\section{RESULTS}

\section{Isolation and Identification of Staphylococcus aureus}

25 isolates of $S$. aureus from 100 samples of blood culture bottles were isolated and identified by fermenting the sugar of mannitol and convert the pink color of the mannitol agar to (yellow) color, on blood agar which appeared as a smooth colony yellow or golden in color, some of the strains produce beta hemolytic or clear zone around the colonies. Morphologically as gram positive cocci arranged in grape-like irregular clusters $\stackrel{(21,22)}{ }$.

\section{Biochemical activity}

S. aureus positive for catalase, coagulase, DNase activity and gelatinase or liquefaction of gelatin $\stackrel{(23,21)}{\text {. }}$ Thus the results showed 25 isolates of $S$. aureus were isolated among 100 positive blood culture bottles or samples.

\section{Isolation of Enterotoxigenic $S$. aureus}

Twenty five isolates of $S$. aureus that isolated from positive blood culture bottles nine of them were ob- 
served as enterotoxin producer by cultural method as shown in figure (1). The result showed in figure (1a) the yellow brain heart infusion agar (BHIA) with special indicator without inoculation with bacterial strain and used as a control. Figure (1-b) showed a positive result (enterotoxin production) which was indicated by a change in the medium color from yellow to red. This was due to the change of phenol red color as respond to $\mathrm{pH}$ changes from (5.4 to 8.2) for isolates no. $(11,23,38,41,67,81,88,89$, and 95)

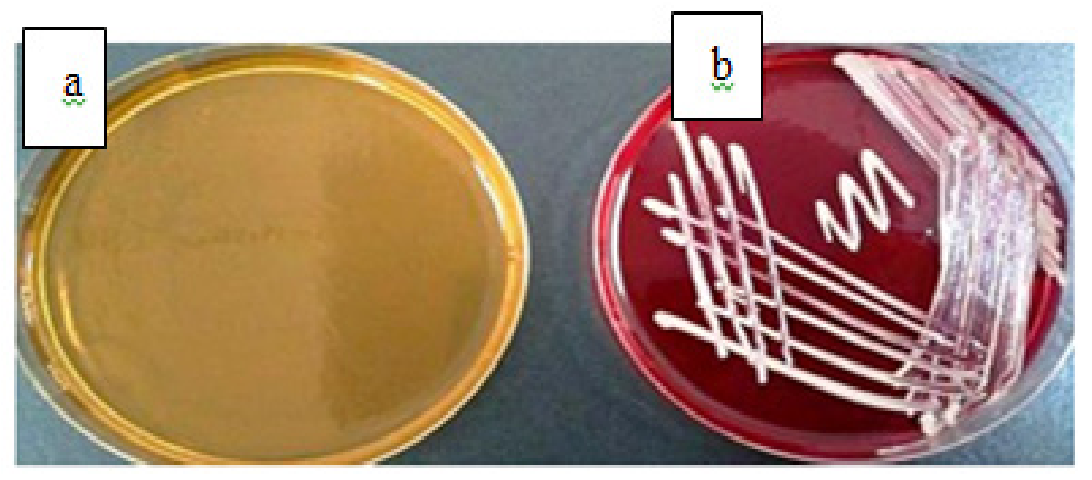

Figure 1. a- Non inoculated brain heart infusion agar. b- $S$. aureus produces enterotoxine.

\section{Plasmids profile analysis}

Plasmid DNA was extracted from $S$. aureus isolates by alkaline lysis ${ }^{13}$. Investigation was done in order to find relationship between enterotoxin and genetic determinants. The results revealed presence of (80 and 55) kb DNA plasmids in staph no.89 isolate and (80) kb DNA plasmid in staph no.81 isolate as showed in figure 2 (lane: 3 and 10). S. aureus no. 89 and 81 isolates were tested for transferability of their DNA plamids to (DH10B E. coli) which were obtained from Science and Health Research Center (SHRC) of Koya University. Transformation process was done successfully as showed in figure 2 (lane: 5 and 11).
The transformed cells were re-streaked onto fresh selective brain heart infusion agar and the results showed positive results after $24 \mathrm{hrs}$ incubation at $37 \mathrm{oC}$ by changing the color of the media from yellow to red, for isolates no. $(11,81,88$ and 89$)$. The results showed that enterotoxin genes of four of the isolates which are located on the plasmids among nine Enterotoxigenic $S$. aureus, as showed in figure (2-B). And, the identities of this four isolates were re-confirmed on the basis of their morphology characteristics and biochemical activities as mentioned before. While, DH10B E.coli doesn't have enterotoxin gene as showed in figure 3 (lane 9) and remain yellow as showed in figure $2 \mathrm{~A}$. 

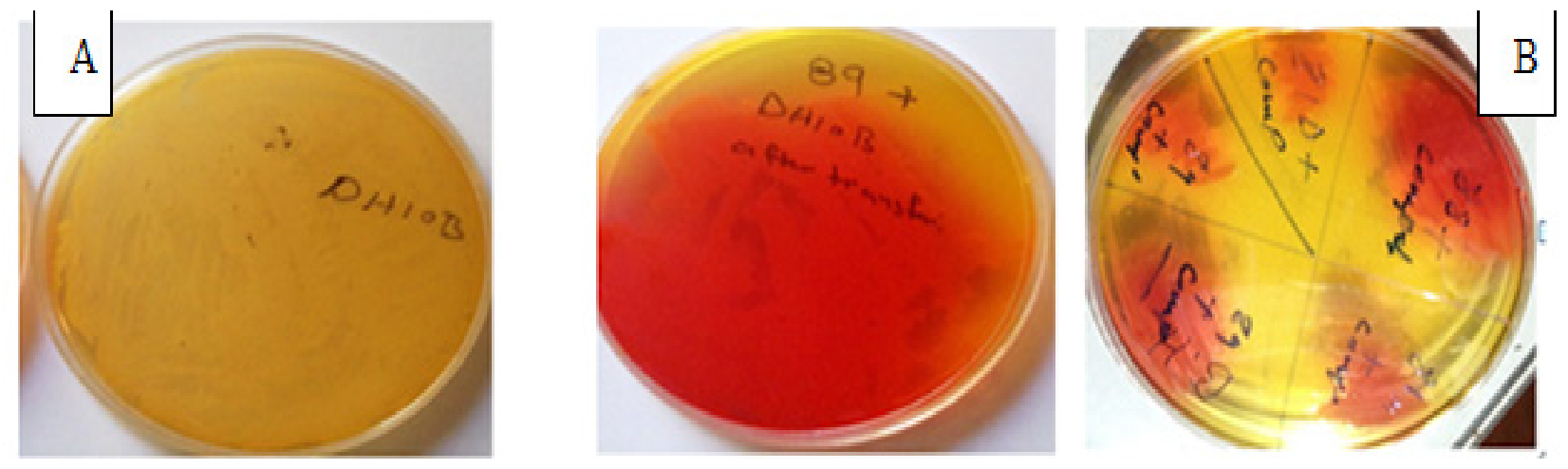

Figure 2. A- DH10B E. coli on enterotoxin selective media. B- Staph no. (11, 81, 88, and 89) after transformation process to $\mathrm{DH} 10 \mathrm{~B}$ E. coli on selective media.

The plasmids were then photographed and UV transillumination was used. $1 \mathrm{~Kb}$ DNA marker was used to determine or measure the size of the plasmid as standard, as demonstrated in figure 3 (lane 1).

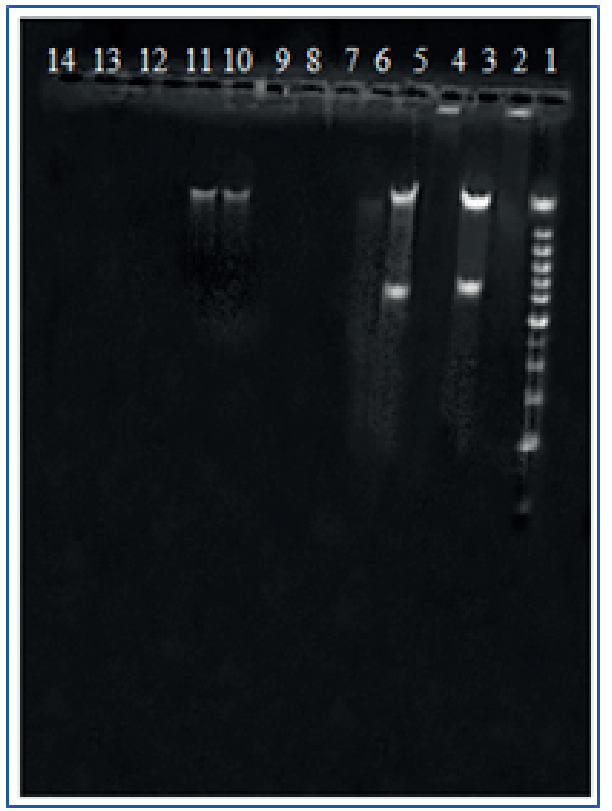

Electrophoreses run at $75 \mathrm{~V}$ for $1: 30 \mathrm{hrs}$.

Lane1: DNA marker $1 \mathrm{~Kb}$.

Lane3: S. aureus isolate No.89.

Lane5: S. aureus isolate No.89 after transformation process to DH10B E.coli.

Lane7: S. aureus isolate No.89 after curing by methanol extract of clove.

Lane8: S. aureus isolate No.89 after curing by methanol extract of cinnamon.

Lane9: DH10B E.coli.

Lane10: S. aureus isolate No.81.

Lane11: S. aureus isolate No.81 after transformation process to DH10B E.coli.

Lane12: S. aureus isolate No.81 after curing by methanol extract of clove.

Lane13: S. aureus isolate No.81 after curing by methanol extract of cinnamon.

Figure 3. Plasmid profile of $S$. aureus isolates no. (89 and 81) before transformation process, after transformation to DH10B E.coli, DH10B E.coli and after curing by (E. caryophyllata and C. zeylanicum).

Curing of plasmid DNA which has carried enterotoxin gene in $S$. aureus isolates by some medicinal plant extracts (E. caryophyllata and C. zeylanicum)

The methanol extract of E. caryophyllata and C. zeylanicum at sub mínimum inhibition concentration (sub MIC) (100 and 5000) $\mu \mathrm{g} / \mathrm{ml}$ respectively. Results showed the genes responsible for relasing enterotox- ins and located on plasmids were affected by plant extracts; as showed in figure 2 (lane 3): staph no.89 have two plasmids with molecular weight of the large one is about $80 \mathrm{~Kb}$ and the other is $55 \mathrm{~Kb}$. Lane 7 and 8: is staph no.89 after treating with E. caryophyllata and $C$. zeylanicum, methanol extracts at concentration $(100$ and 5000$) \mu \mathrm{g} / \mathrm{ml}$ respectively affected the genes responsible for producing enterotoxins and eliminated both plasmids. Lane 9: is DH10B E. coli. 
Lane 10: is staph no. 81 which has one plasmid with molecular weight about 80kb. Lane (12 and 13): Is staph no. 81 after treating with (Eugenia caryophyllata and Cinnamomum zeylanicum) at concentration (100 and 5000) $\mu \mathrm{g} / \mathrm{ml}$ respectively eliminated the plasmid with the genes responsible of producing enterotoxins.

\section{DISCUSSION}

In total, $100 \mathrm{BacT} / \mathrm{ALERT}$ positive blood culture bottles 25 of them were identified as s. aureus, this results agree with the study of ${ }^{(24)}$ that showed S. aureus bacteremia was found in nine $(12 \%)$ of 77 patients at a median time of 4 days after CVC removal that obtained from blood culture. And the study of ${ }^{(25)}$ demonstrated from 150 BacT/ALERT blood cultures in which a direct Gram stain showed Gram positive cocci resembling staphylococci were examined. Cultures of the broths revealed 66 positive for $S$ aureus, 81 positive for coagulase negative staphylococci, and three positive for species of micrococcus.

Then, the present study demonstrated twenty five isolates of $S$. aureus that isolated from positive blood culture bottles nine of them were observed as enterotoxin producer, this agree with the results of (26) shows that the production of enterotoxin A, B, C and D by 196 S. aureus strains isolated from blood cultures and 95 strains from nasal carriers was investigated. $30.6 \%$ of the bacteremia strains and $40 \%$ of the nasal strains produced enterotoxins. Enterotoxigenic strains of $S$. aureus produce at least 19 variants of enterotoxins. Another study recorded different percentage of toxin-positive isolates of s. aureus, the overall rate were $67 \cdot 9 \% \frac{(27)}{2}$. This is not in accordance with the present study. It may be due to environments, geographycal región and nutritional factors. The results determined from nine samples which they have enterotoxin four of the enterotoxin gene isolates are located on the plasmids, and the study of $\stackrel{(28)}{~ s h o w e d ~ s t a p h y l o c o c c a l ~ p l a s m i d s ~ m a y ~ a l s o ~ e n-~}$ code toxin genes. For example, a large $37.5-\mathrm{kb} S$. aureus plasmid, pRW001, contains genes encoding exfoliative toxin B, bacteriocin, and bacteriocin immunity. Another researcher ${ }^{(29)}$ revealed in his study the results of molecular tests for the detection of genes encoding the toxins SEA, SEB, SEC, SED, SEE, SEG, SEH, SEI, SEIJ, SEIP and SER. Of the 481 strains of $S$. aureus tested, 255 (53\%) were positive for one or more SE genes and 35 different enterotoxin gene. The genes encoding for SED, SER and SElJ are carried on the same plasmid and among all the profiles, sed-ser-selj (15\%) was the most common, followed by seg-sei $(123 \%)$. These latter genes are likely to be carried together on the EGC. SE genes carried on plasmid and EGC were the most frequently present within the isolates bearing SE genes.

The present study demonstrated curing or elliminating those plasmids that have carried enterotoxigenic genes by E. caryophyllata and C. zeylanicum methanol extracts. This agree with the study of Abhinav et al., ${ }^{(8)}$ who illustrated that $S$. aureus produces a wide range of exotoxins that facilitate its pathogenesis in the host. Plant compounds at their sub-inhibitory concentrations were found to modulate toxin production in $S$. aureus. Essential oils from clove and cinnamon reduced $S$. aureus alpha-hemolysin, enterotoxin A and enterotoxin B production in vitro. Also, Cruickshank et al., $\stackrel{(30)}{\longrightarrow}$ reported similar findings and observed that eugenol (active component in clove oil) significantly reduced the production of alpha hemolysin, enterotoxin A and B, and toxic shock syndrome toxin in vitro. There are many studies about eliminating or affecting on plasmid with its virulence factors such as (biofilm, resistant genes, enterotoxin genes and others). The study of Adel

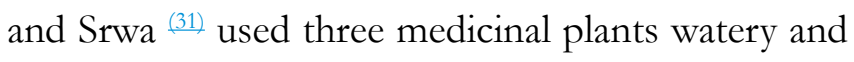


alcohol extracts for eliminating resistant genes of $E$. coli, also the study of Muhammad et al., $\stackrel{(32)}{\longrightarrow}$ used three medicinal plant extracts for curing resistant genes of Salmonella spp.

\section{CONCLUSIONS}

This study shows that only nine isolates of enterotoxigenic $S$. aureus were isolated from 25 coagulase positive $S$. aureus in the 100 positive blood culture bottles. The genes of four of the isolates which were responsible for producing enterotoxin are located on plasmids, these plasmids were transferred to DH10B E.coli successfully by transformation process. Then, SMIC (sub minimum inhibition concentration) of methanol extracts of medicinal plants (Eugenia caryophyllata and Cinnamomum zeylanicum) were acting as curing agent on the enterotoxin gene.

\section{REFERENCES}

1. Michael O. Staphylococcus aureus toxins. J NIH Public Access Author Manuscript. 2014; 0: 32-37 https://doi.org/10.1016/j.mib.2013.11.004

2. Manoharan M, Jayaraman S, Illanchezian S, and Jayasekar J. Homologous Resistant Groups (HRGs) in Multidrug Resistant Staphylococcus aureus Isolated from Retail Foods in Vadapalani, Chennai. The Internet J of Micr. 2008; 7 (1):1-6 https://doi.org/10.5580/103c

3. Qinfang Q, Karen E, and James EK. Rapid Identification of Staphylococcus aureus Directly from Bactec Blood Culture Broth by the BinaxNOW S. aureus Test. J Clin Microbiol. 2014; 52(1): 319320. https://doi.org/10.1128/JCM.02291-13

4. Lodise TP, McKinnon PS, Swiderski L, and Rybak MJ. Outcome analysis of delayed antibiotic treatment for hospital-acquired Staphylococcus aureus bacteremia. J of Clin inf dise. 2003; 36:14181423 https://doi.org/10.1086/375057

5. Finlay BB, Falkow S. Common themes in microbial pathogenicity revisited. J Microbiol Mol Biol Rev. 1997; 61 (2):136-69
6. Taylor CM, Roberts IS. Capsular polysaccharides and their role in virulence. In Concepts in Bacterial Virulence. Karger Medical and Scientific Publishers: Contrib Microbiol. Basel, Karger, 2005, vol 12, pp 55-66

https://doi.org/10.1159/000081689

7. Wu HJ, Wang AH, Jennings MP. Discovery of Virulence Factors of Pathogenic Bacteria. J Curr. Opin. Chem. Boil. 2008;12: 93-101

https://doi.org/10.1016/j.cbpa.2008.01.023

8. Abhinav U, Shankumar M, Hsinbai Y, Meera SN, Varunkumar B, and Kumar V. Inhibiting Microbial Toxins Using Plant-Derived Compounds and Plant Extracts. J of Med. 2015; 2: 186-211 ISSN 2305-6320

https://doi.org/10.3390/medicines2030186

9. Izenberg HD. Blood Cultures-General Detection and Interpretation. In Clinical Microbiology Procedures Handbook. 2003; Vol. 1: P. 3.4.1.13.4.1.19

10. Nneoma Confidence; JeanStephanie Anyanwu; Walter Chinaka John. Conventional and rapid methods for identification of Staphylococcus aureus from clinical specimens". American Journal of Biomedical and Life Sciences [internet]. 2013; Volume 1. P. 41-43.

https://doi.org/10.11648/j.ajbls.20130103.11

11. Abdulameer A. Al-Mussawi. Detection of Staphylococcus aureus and Methicillin Resistant Staphylococcus aureus (MRSA) From Human Clinical Specimens Using Conventional Biochemical Tests and Chromogenic Media. In J of App Res. 2014; 4: 7. https://doi.org/10.15373/2249555X/FEB2014/150

12. Cenci-Goga BT, Karama M, Rossitto PV, Morgante RA and Cullor JS. Eterotoxin Production by Staphylococcus aureus Isolated from Mastitic Cows. J Food Prot. 2003; 66(9):1693-1696.

https://doi.org/10.4315/0362-028X-66.9.1693

13. Birnboim HC, Doly JA. A Rapid Alkaline Extraction Procedure for Screening Recombinant Plasmid DNA. J Nucleic Acids Res. 1979; 7: 1513-23. https://doi.org/10.1093/nar/7.6.1513

14. Nancy T, and Janine T. Fundamental Bacterial Genetic. Blackwell Since Ltd a Blackwell publishing company. 2004. 350 Main Street, Malden, MA02148- 5020. USA. 
15. Srwa AM, Mohammed AH, and Dereh LM. Treating Antibiotic Resistance Genes in Proteus Spp. were Isolated from Renal Stone Patients by Crataegus rbipidophylla and Adiantum capillus. KJAR. 2018; 3 (2):102-106.

https://doi.org/10.24017/10.24017/science.2018.2.17

16. Sambrook J, Fritsch EF and Maniatis T. Molecular Cloning:A Laboratory Manual. 2nd ed. Cold Spring Harbor, N.Y: 1989. Cold Spring Harbor Laboratory Press

17. Puhler A, and Timmis NK. Advanced in molecular genetics. springerverlag berlin Heidelberg, New York., 1984.

\section{https://doi.org/10.1007/978-3-642-69305-2}

18. Pei YL, John C, Chih-YH, and Yong HK. Agarose Gel Electrophoresis for the Separation of DNA Fragments. JoVE; 2012 (62): 3923.

https://doi.org/10.3791/3923

19. Handa SS, Khanuja SPS, Longo G, Rakesh DD. Extraction Technologies for Medicinal and Aromatic Plants.1st ed. no. 66. 2008; Italy United Nations Industrial Development Organization and the International Centre for Science and High Technology.

20.Cruickshank R, Duguid JD, Marmion BP and Swain RHA. Medical Microbiology, The Practice of Medical Microbiology.1975; 12th ed.:vol.1 Churchill Livingstone, London and New York.

21. Brooks GF, Caroll KC, and Morse SA. Staphylococcus (Jawetz).Melnick and Adelberg's, Medical Microbiology. 24th ed. 2007; the McGraw-Hill.New York.

22.Dubey RC and Maheshwari DK. Microbiology .1st ed. P.1034.

23.Benson J M. Microbiological Applications; Laboratory Manual in General Microbiology. McGraw Hill 8th ed. 2001: 168-262.

24. Ruhe J J and Menon A. Clinical Significance of Isolated Staphylococcus aureus Central Venous Catheter Tip Cultures. J Med Sci. 2006; 12: 933-936.

https://doi.org/10.1111/j.1469-0691.2006.01491.x

25. Murdoch D R, and Greenlees R L. Rapid Identification of Staphylococcus aureus from BacT/ALERT Blood Culture Bottles by Direct Gram Stain
Characteristics. J Clin Pathol. 2004;57(2):199_ 201. https://doi.org/10.1136/icp.2003.10538

26. Roder B, Enksen NH, Nelsen LP, Slotsbieng T, Rosdahi VT and Esoersen F. No Difference in Enterotoxin Production among Staphylococcus aureus Strains Isolated from Blood Compared with Strains Isolated from Healthy Carriers. J Med Microbiol. 1995; 42 (1):7-43. www.ncbi.nlm.nih. gov/pubmed/7739024

https://doi.org/10.1099/00222615-42-1-43

27. Nashev D, Toshkova K, Bizeva L, Akineden Ö, Lämmler C, and Zschöck M. Distribution of Enterotoxin Genes Among Carriage- and Infection-Associated Isolates of Staphylococcus aureus; J Appl Microbiol.2007;45(6):(681-685)

https://doi.org/10.1111/j.1472-765X.2007.02254.x

28.Jackson MP, Iandolo JJ. Cloning and Expression of the Exfoliative Toxin B Gene from Staphylococcus aureus J Bacteriol. 1986; 166:574-580.

https://doi.org/10.1128/ib.166.2.574-580.1986

29.Bianchi DM, Gallina S, Bellio A, Chiesa F, Civera T, and Decastelli L. Enterotoxin Gene Profiles of Staphylococcus aureus Isolated from Milk and Dairy Products in Italy. J Appl Microbiol. 2013; 58: 190-196. https://doi.org/10.1111/lam.12182

30.Qiu J, Feng H, Lu J, Xiang H, Wang D, Dong J, Deng X. Eugenol Reduces the Expression of Virulence-Related Exoproteins in Staphylococcus aureus. J Appl Environ Microb. 2010; 76: 58465851. https://doi.org/10.1128/AEM.00704-10

31. Adel KK, Srwa A Mohammed. The Potential of Aqueous and Alcoholic Extracts of Three Medicinal Plants Quercus infectoria Oliv (quercus) Linum usitatissimum (flaxseed) and Cinnamomum zeylanicum (cinnamon) as Antibacterial Agents. J BIOL SC. 2010; 2 (5) ISSN: 2041-076X Maxwell Science Publication.

32. Muhammad OM, Srwa A Mohammed, Ibrahim SH. Bacteriological and Molecular Genetic Study of Salmonella typhi Isolated from Patients with Enteric Fever. J of Koya University. 2009; NO.12 ISSN 2073-0713. 